Melanie C. Matheson · Justine A. Ellis · Joan Raven

E. Haydn Walters · Michael J. Abramson

\title{
Association of IL8, CXCR2 and TNF- $\alpha$ polymorphisms and airway disease
}

Received: 1 September 2005/ Accepted: 4 November 2005/Published online: 21 January 2006

(C) The Japan Society of Human Genetics and Springer-Verlag 2006

\begin{abstract}
Chronic obstructive pulmonary disease (COPD) is a disease characterised by inflammation of the peripheral airways involving many inflammatory cells and mediators. IL8 is an important inflammatory mediator that is responsible for the migration and activation of neutrophils. Cellular activity of IL8 is mediated by the receptor CXCR2, and transcription of $I L 8$ is controlled by the cytokine tumour necrosis factor

higher diffusing capacity $(P=0.03)$ and $\mathrm{FEF}_{25-75}$ $(P=0.02)$. No association with the IL8 -251 polymorphism was found. Our results suggest that $T N F-\alpha$ is associated with COPD-related phenotypes and the CXCR2 +785 SNP may be important in protecting against pulmonary inflammation. These genes may be important candidates in the modulation of the inflammatory response in the airways.
\end{abstract} $(\mathrm{TNF} \alpha)$. The aim of our study was to investigate the influence of single nucleotide polymorphisms in ILS, $C X C R 2$ and $T N F-\alpha$ on lung function and respiratory symptoms in subjects from Melbourne, Australia. A total of 1,232 participants completed a detailed respiratory questionnaire, spirometry and measurement of gas transfer. Genotyping for the IL8 $-251 \mathrm{~T} \rightarrow \mathrm{A}$, $C X C R 2+785 \mathrm{C} \rightarrow \mathrm{T}$ and $T N F-\alpha-308 \mathrm{G} \rightarrow \mathrm{A}$ polymorphisms was performed using the tetra-primer ARMS-PCR method. The $T N F-\alpha$ A allele was associated with a reduced $\mathrm{FEF}_{25-75}(P=0.03)$. Inheritance of the $C X C R 2 \mathrm{~T}$ allele was associated with significantly

M.C. Matheson · M.J. Abramson

Department of Epidemiology and Preventive Medicine,

Monash University, Victoria, Australia

J.A. Ellis

Department of Physiology, University of Melbourne, Victoria, Australia

J. Raven

Department of Allergy, Immunology \& Respiratory Medicine, The Alfred Hospital, Victoria, Australia

E.H. Walters

Cardio-Respiratory Research Group, School of Medicine, University of Tasmania, Hobart, Australia

M.C. Matheson ( $\square)$

Centre for Molecular, Environmental, Genetic \& Analytic Epidemiology, School of Population Health,

The University of Melbourne, Level 2 / 723 Swanston Street, Carlton, Victoria, 3053, Australia

E-mail: momat@unimelb.edu.au

Tel.: +61-3-83440713

Fax: +61-3-93495815
Keywords TNF- $\alpha \cdot \mathrm{CXCR} 2 \cdot \mathrm{IL} 8 \cdot$ Lung function $\cdot$ Polymorphism

\section{Introduction}

Chronic respiratory diseases such as chronic obstructive pulmonary disease (COPD) and asthma are characterised by airflow obstruction and a chronic persistent inflammatory process. The inflammatory process is a complex interaction between many cellular mechanisms, inflammatory mediators and effects (Barnes 2000).

IL8 is an important pro-inflammatory cytokine that primarily mediates the activation and migration of neutrophils into tissue from peripheral blood (Strieter 2002). High concentrations of IL8 have been found in the bronchoalveolar lavage fluid (BAL) of both asthma (Norzila et al. 2000) and COPD (Pesci et al. 1998; Rutgers et al. 2000) patients. Cellular activity of IL8 is mediated by two receptors, IL8 receptor 1 (CXCR1) and IL8 receptor 2 (CXCR2) (Renzoni et al. 2000). Mouse knockout studies have suggested CXCR2 is a major mediator of neutrophil migration (Cacalano et al. 1994) and, in humans with COPD exacerbations, the intensity of $C X C R 2$ mRNA expression was found to be significantly positively correlated with increased CXCR2 (Qiu et al. 2003). Another important inflammatory cytokine is tumour necrosis factor $\alpha(\mathrm{TNF}-\alpha)$, which is released from stimulated alveolar macrophages (Hajeer and Hutchinson 2000). The level of TNF- $\alpha$ is also elevated in BAL and sputum of patients with asthma (Thomas 2001) and COPD (Sun et al. 1998). Importantly TNF- $\alpha$ also 
activates nuclear factor- $\kappa \mathrm{B}(\mathrm{NF}-\kappa \mathrm{B})$, which switches on transcription of IL8 (Rahman et al. 2002).

Several polymorphisms in IL8 have been identified and one at position -251 (rs4073) of the IL8 promoter has been shown to be associated with greater IL8 expression (Hull et al. 2000). Three novel polymorphisms have been identified in CXCR2 including the CXCR2 $+785 \mathrm{C} \rightarrow \mathrm{T}$ (rs2230054) polymorphism located in exon 11 that results in a silent codon change (Renzoni et al. 2000). For $T N F-\alpha$, a polymorphism at position -308 (rs1800629) of the $T N F-\alpha$ promoter has been extensively studied because the TNF- $\alpha-308 \mathrm{~A}$ allele has been shown to be associated with higher transcriptional activity (Hajeer and Hutchinson 2000).

Previous genetic studies have revealed some information on the involvement of these genes in respiratory phenotypes. A study of the $I L 8-251 \mathrm{~T} \rightarrow$ A polymorphism with risk of COPD (Arinir et al. 2005) failed to detect an association. A genome-wide scan has linked the region on chromosome $2 \mathrm{q}$ near the location of the $C X C R 2$ gene to spirometric phenotypes related to COPD (DeMeo et al. 2004; Silverman et al. 2002). No association studies of CXCR2 have been reported; however, a recent study reported an association between two novel polymorphisms in CXCRI and COPD (Stemmler et al. 2005). Additionally, due to its important role in the inflammatory process and its high level in the sputum of COPD patients, TNF- $\alpha$ has been well studied as an obvious candidate gene for COPD. To date there have been seven case-control studies of COPD and the TNF- $\alpha$ -308 polymorphism but the results have been inconsistent (Ferrarotti et al. 2003; Higham et al. 2000; Huang et al. 1997; Ishii et al. 2000; Keatings et al. 2000; Patuzzo et al. 2000; Sakao et al. 2001; Sandford et al. 2001).

Due to the overlapping and interactive roles of IL8, CXCR2 and TNF- $\alpha$ in the inflammatory process it is possible that polymorphisms in these genes may influence risk of airway inflammation and obstruction. To examine this we performed an association study using participants in an epidemiological study of risk factors for COPD. This representative sample of middle-aged and older adults from the population of Victoria, Australia, who because of their advanced age are likely to have developed airflow limitation and respiratory symptoms were genotyped for three previously described biallelic single nucleotide polymorphisms (SNPs): IL8 $-251 \mathrm{~T} \rightarrow \mathrm{A}$, $C X C R 2+785 \mathrm{C} \rightarrow \mathrm{T}$ and $T N F-\alpha-308 \mathrm{G} \rightarrow \mathrm{A}$. This paper presents an analysis of the effect of these polymorphisms, individually and in combination, on lung function and respiratory symptoms. The interaction with cigarette smoking has also been examined.

\section{Materials and methods}

\section{Participants}

Recruitment and pulmonary function testing are described in detail elsewhere (Matheson et al. 2005).
Briefly, 1,232 subjects randomly selected from the general population were recruited to be part of the study. Ninety four percent $(n=1,167)$ of the participants were of Caucasian descent and, of these, 1,032 $(88.4 \%)$ were successfully genotyped for $I L 8, C X C R 2$ and $T N F-\alpha$. In order to assess the association with COPD-related phenotypes, we removed those subjects with current asthma from the analysis (wheeze in the last 12 months and bronchial hyper-reactivity). The results for these remaining $n=828$ subjects are presented. The study was approved by the Ethics Committee at The Alfred Hospital and Monash University in Melbourne Australia. All participants gave written informed consent.

\section{Outcomes}

Spirometry and diffusing capacity (TLco) was performed according to American Thoracic Society (ATS) criteria (American Thoracic Society 1994, 1995). Predicted values for $\mathrm{FEV}_{1}, \mathrm{FVC}$ and $\mathrm{FEF}_{25-75}$ were calculated from age, height and gender using the equations of Gore et al. (1995), and for TLco using the equations of Quanjer et al. (1983).

\section{Genotyping}

Genotyping for the IL8 $-251 \mathrm{~T} \rightarrow \mathrm{A}$, CXCR2 +785 $\mathrm{C} \rightarrow \mathrm{T}$ and $T N F-\alpha-308 \mathrm{G} \rightarrow \mathrm{A}$ polymorphisms was performed using the PCR tetra-primer ARMS method (Ye et al. 2001). Primers were designed using the computer program made available by the authors of the method. The four primers required to genotype each of the polymorphisms are listed in Table 1. All genotyping was performed blind with respect to participant characteristics. Approximately $50 \mathrm{ng}$ DNA was amplified in a $20 \mu \mathrm{l}$ PCR mix. This mix contained $1 \times$ reaction buffer, $2.5 \mathrm{mM} \mathrm{MgCl}_{2}, 250 \mu \mathrm{M}$ dNTP (GeneAmp, Applied Biosystems, Foster City, CA), 1 U AmpliTaq Gold DNA polymerase (Applied Biosystems) and $0.5 \mu \mathrm{M}$ of each primer. The outer primers were diluted to $1: 10$ of the concentration of the inner primers to enhance specificity. The PCR cycling conditions were $95^{\circ} \mathrm{C}$ for $10 \mathrm{~min}$, followed by 35 cycles of $94^{\circ} \mathrm{C}$ for $1 \mathrm{~min}, 1 \mathrm{~min}$ at the annealing temperature specified in Table 1 and then $72^{\circ} \mathrm{C}$ for $1 \mathrm{~min}$, followed by a final extension for $10 \mathrm{~min}$ at $72^{\circ} \mathrm{C}$. The PCR products were resolved by electrophoresis on a $2 \%$ agarose gel stained with ethidium bromide. To validate the genotyping protocol, $10 \%$ of the total sample was re-genotyped using the single nucleotide primer extension method (SNuPe) (Amersham Biosciences, Little Chalfont, UK). The SNuPe method was performed as described in the manufacturer's instructions on an Amersham Biosciences MegaBACE system. 
Table 1 Details of the primers, annealing temperature and fragment sizes for the single nucleotide polymorphisms (SNPs) genotyped using the tetra-primer-PCR method

\begin{tabular}{|c|c|c|c|}
\hline SNP & Primer sequence & $T_{\mathrm{m}}$ & Fragment size \\
\hline $\begin{array}{l}T N F-\alpha-308 \mathrm{G} \rightarrow \mathrm{A} \\
(\mathrm{rs} 1800629)\end{array}$ & $\begin{array}{l}\text { Forward inner primer (T allele): } \\
\text { 5'-TGGAGGCAATAGGTTTTGAGGGGCAGGA } \\
\text { Reverse inner primer (A allele): } \\
\text { 5'-TAGGACCCTGGAGGCTGAACCCCGTACC } \\
\text { Forward outer primer }\left(5^{\prime}-3^{\prime}\right) \text { : } \\
\text { 5'-ACCCAAACACACGCCTCAGGACTCAACA } \\
\text { Reverse outer primer }\left(5^{\prime}-3^{\prime}\right) \text { : } \\
\text { 5'-AGTTGGGGACACGCAAGCATGAAGGATA }\end{array}$ & $68^{\circ} \mathrm{C}$ & $\begin{array}{l}154 \mathrm{bp} \text { (A allele) } \\
224 \mathrm{bp} \text { (G allele) } \\
323 \mathrm{bp} \text { (two outer primers) }\end{array}$ \\
\hline $\begin{array}{l}I L 8-251 \mathrm{~T} \\
(\mathrm{rs} 4073)\end{array}$ & $\begin{array}{l}\text { Forward inner primer (T allele): } \\
\text { 5'-GTTATCTAGAAATAAAAAAGCATACAA } \\
\text { Reverse inner primer (A allele): } \\
\text { 5'-CTCATCTTTTCATTATGTCAGAG } \\
\text { Forward outer primer }\left(5^{\prime}-3^{\prime}\right): \\
\text { 5'-CATGATAGCATCTGTAATTAACTG } \\
\text { Reverse outer primer }\left(5^{\prime}-3^{\prime}\right) \text { : } \\
\text { 5'-CACAATTTGGTGAATTATCAAA }\end{array}$ & $58^{\circ} \mathrm{C}$ & $\begin{array}{l}169 \mathrm{bp} \text { (T allele) } \\
228 \mathrm{bp} \text { (A allele) } \\
349 \mathrm{bp} \text { (two outer primers) }\end{array}$ \\
\hline
\end{tabular}

Statistical analysis

Statistical analysis was performed using the statistical package STATA (version 6 STATA Corporation, TX). Hardy Weinberg Equilibrium (HWE) was tested by means of a $\chi^{2}$ goodness of fit test. Multiple regression or logistic regression analysis was used to examine the association between genotype and continuous or binary outcomes. Outcomes investigated included: lung function (including $\mathrm{FEV}_{1}$ and TLco) and respiratory symptoms in the last 12 months (including wheeze, morning and chronic cough, morning and chronic sputum, dyspnoea grade 3 and nocturnal chest tightness). Covariates included in the models were age, gender, smoking status and pack years of smoking. Pack-years were calculated as number of cigarettes smoked per day divided by 20 multiplied by the number of years of smoking.

\section{Results}

General characteristics

The mean (SD) age of the subjects was 57.8 $( \pm 7.4)$ years. There was no significant excess of either gender in the sample, with $52.5 \%$ males $(n=435)$. The prevalence of current smokers was $11 \%(n=91)$, past smokers $38.4 \% \quad(n=318)$ and never smokers $50.6 \%$ $(n=419)$. The lung function parameters of the study group are presented in Table 2 and the prevalence of respiratory symptoms for the study group are presented in Table 3.
Genotyping and allele frequencies

Figures 1, 2 and 3 depict representative gel electrophoresis results for the three genes. Table 4 shows the genotype and allele frequencies for the TNF- $\alpha, C X C R 2$ and IL8 polymorphisms. Both the $C X C R 2$ and $T N F-\alpha$ polymorphisms were in HWE (CXCR2 + $785 P=0.53$; TNF $-P=0.62)$; however, IL8 was not found to be in HWE $(P=0.02)$. To confirm the genotyping results of IL8, $10 \%$ of the sample were repeated using an alterative

Table 2 Lung function in the study group $(n=828)$

\begin{tabular}{ll}
\hline Parameter & Mean \pm SD \\
\hline FEV $_{1}$ & $3.26 \pm 0.81$ \\
FVC $_{\text {FEV }} /$ FVC & $4.27 \pm 0.99$ \\
$\mathrm{FEF}_{25-75}$ & $76.1 \pm 7.4$ \\
Tlco & $2.87 \pm 1.14$ \\
Kco & $23.5 \pm 5.56$ \\
Log dose response slope & $4.03 \pm 0.64$ \\
\hline
\end{tabular}

Table 3 Respiratory symptoms in the study group $(n=828)$

\begin{tabular}{lc}
\hline Symptom & $n(\%)$ \\
\hline Wheeze & $189(22.8)$ \\
Nocturnal chest tightness & $101(12.2)$ \\
Nocturnal SOB & $59(7.1)$ \\
Morning cough & $120(14.5)$ \\
Chronic cough & $70(8.5)$ \\
Morning phlegm & $54(6.5)$ \\
Chronic phlegm & $23(2.8)$ \\
Dyspnoea & $15(1.8)$ \\
\hline
\end{tabular}




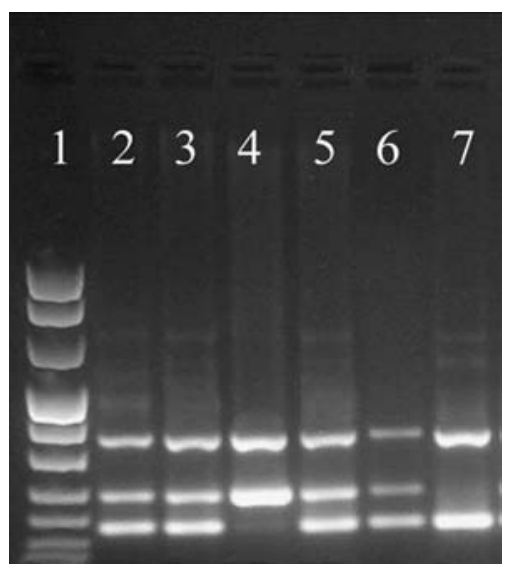

Fig. 1 Electrophoresis gel of the IL8 -251 T $\rightarrow$ A PCR-tetra primer method. Bands: Top Control (349 bp), middle A allele (228 bp), bottom T allele (169 bp). Lanes: 1 DNA size marker; 2, 3, $5,6 \mathrm{~A} / \mathrm{T}$ heterozygotes; 4 AA homozygote; 7 TT homozygote

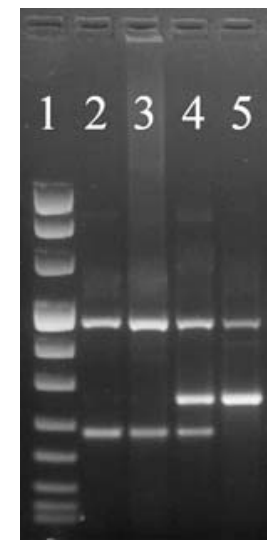

Fig. 2 Electrophoresis gel of the $C X C R 2+785 \mathrm{C} \rightarrow \mathrm{T}$ PCR-tetra primer method. Bands: Top Control (451 bp), middle $\mathrm{T}$ allele (281 bp), bottom C allele (226 bp). Lanes: 1 DNA size marker; $4 \mathrm{~T} /$ $\mathrm{C}$ heterozygote; 2, 3 CC homozygotes; 5 TT homozygote

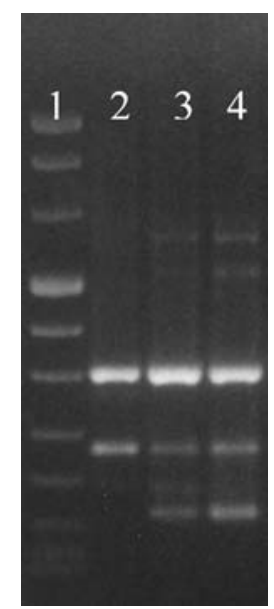

Fig. 3 Electrophoresis gel of the $T N F-\alpha-308 \mathrm{G} \rightarrow$ A PCR-tetra primer method. Bands: Top Control $(323 \mathrm{bp}$ ), middle $\mathrm{G}$ allele (224 bp), bottom A allele (154 bp). Lanes: 1 DNA size marker; 3, 4 $\mathrm{G} / \mathrm{A}$ heterozygotes, $2 \mathrm{GG}$ homozygote
Table 4 Genotype and allele frequencies

\begin{tabular}{lllll}
\hline SNP & Genotype & $\begin{array}{l}\text { Genotype } \\
\text { frequency } \\
n(\%)\end{array}$ & Allele & $\begin{array}{l}\text { Allele } \\
\text { frequency } \\
(\%)\end{array}$ \\
\hline$I L 8-251 \mathrm{~A}>\mathrm{T}$ & $\mathrm{A} / \mathrm{A}$ & $183(22.1)$ & $\mathrm{A}$ & 44.8 \\
& $\mathrm{~A} / \mathrm{T}$ & $375(45.3)$ & $\mathrm{T}$ & 55.3 \\
& $\mathrm{~T} / \mathrm{T}$ & $270(32.6)$ & & \\
$C X C R 2+785 \mathrm{C}>\mathrm{T}$ & $\mathrm{C} / \mathrm{C}$ & $215(26.0)$ & $\mathrm{C}$ & 50.4 \\
& $\mathrm{~T} / \mathrm{C}$ & $405(48.9)$ & $\mathrm{T}$ & 49.6 \\
& $\mathrm{~T} / \mathrm{T}$ & $208(25.1)$ & & \\
$T N F-\alpha-308 \mathrm{~A}>\mathrm{G}$ & $\mathrm{A} / \mathrm{A}$ & $24(2.9)$ & $\mathrm{A}$ & 17.8 \\
& $\mathrm{~A} / \mathrm{G}$ & $246(29.7)$ & $\mathrm{G}$ & 82.3 \\
& $\mathrm{G} / \mathrm{G}$ & $558(67.4)$ & & \\
\hline
\end{tabular}

method called SNuPe. All results were found to be concordant.

Lung function parameters and $T N F-\alpha, C X C R 2$ and $I L 8$

The association between the lung function indices and the polymorphisms are presented in Table 5 . There was no association between any of the lung function parameters and IL8. Individuals with the $C X C R 2+785$ TT genotype had a significantly better TLco \% predicted and the CXCR2-TC genotype was associated with significantly better $\mathrm{FEF}_{25-75} \%$ predicted. When the TT and TC genotypes were combined, the $\mathrm{T}$ allele was associated with a significantly better $\mathrm{FEF}_{25-75}(0.16,95 \% \mathrm{CI}$ $0.008-0.31, P=0.04)$. For $T N F-\alpha$, individuals with the GA genotype had a significantly reduced $\mathrm{FEF}_{25-75}$ $\%$ predicted. When the $\mathrm{A} / \mathrm{A}$ and $\mathrm{A} / \mathrm{G}$ genotypes were combined, inheritance of at least one $\mathrm{A}$ allele was associated with borderline statistically significantly reduced $\mathrm{FEF}_{25-75}(-0.14,95 \% \mathrm{CI}-0.28-0.005, P=0.06)$. However, there was no association with any of the other lung function parameters.

Because of the importance of cigarette smoking in the inflammatory process, an interaction with smoking was examined by fitting a genotype $\times$ smoking interaction term in the models. However, there were no significant interactions found between any of the genes and cigarette smoking. Nor was there any evidence of an interaction between any of the genes when gene $\times$ gene interaction terms were fitted to the models (data not shown).

Respiratory symptoms and $T N F-\alpha, C X C R 2$ and $I L 8$

No significant associations were found between any of the respiratory symptoms and the $I L 8, \mathrm{TNF}-\alpha$ or $C X C R 2$ polymorphisms. Those individuals with the $T N F-\alpha$-AA genotype had an increased risk of dyspnoea but this did not reach statistical significance (Table 6). Those with self-reported respiratory symptoms had significantly worse lung function than those without symptoms (data not shown). 
Table 5 Lung function parameters by $C X C R 2$ and $T N F-\alpha$ genotype

\begin{tabular}{|c|c|c|c|c|c|}
\hline \multirow{2}{*}{$\frac{\text { Polymorphism }}{T N F-\alpha-308}$} & \multicolumn{3}{|c|}{ Genotype $($ mean $\pm \mathrm{SD})$} & \multirow{2}{*}{$\begin{array}{l}\text { Regression coefficient } \\
\text { A/A vs } G / G \text { genotype }\end{array}$} & \multirow{2}{*}{$\frac{(95 \% \text { CI }) P \text { value }^{\mathrm{a}}}{\text { G/A vs } \mathrm{G} / \mathrm{G} \text { genotype }}$} \\
\hline & $\mathrm{A} / \mathrm{A}(n=24)$ & $\mathrm{A} / \mathrm{G}(n=246)$ & $\mathrm{G} / \mathrm{G}(n=558)$ & & \\
\hline $\mathrm{FEV}_{1}$ & $3.15 \pm 0.87$ & $3.26 \pm 0.81$ & $3.26 \pm 0.81$ & $0.05(-0.15,0.25)$ & $-0.05(-0.12,0.03)$ \\
\hline $\mathrm{FEV}_{1} / \mathrm{FVC}$ & $76.7 \pm 5.08$ & $75.5 \pm 6.9$ & $76.4 \pm 7.65$ & $0.53(-2.34,3.41)$ & $-0.80(-1.86,0.26)$ \\
\hline $\mathrm{FEF}_{25-75}$ & $2.76 \pm 0.98$ & $2.79 \pm 1.12$ & $2.91 \pm 1.16$ & $0.004(-0.39,0.40)$ & $-0.15(-0.29,-0.0005)^{*}$ \\
\hline TLco & $22.7 \pm 5.74$ & $23.6 \pm 5.56$ & $23.6 \pm 5.56$ & $0.53(-0.84,1.89)$ & $-0.22(-0.72,0.28)$ \\
\hline$C X C R 2+785$ & $\mathrm{C} / \mathrm{C}(n=215)$ & $\mathrm{T} / \mathrm{C}(n=405)$ & $\mathrm{T} / \mathrm{T}(n=208)$ & $\mathrm{T} / \mathrm{T}$ vs $\mathrm{C} / \mathrm{C}$ genotype & $\mathrm{T} / \mathrm{C}$ vs $\mathrm{C} / \mathrm{C}$ genotype \\
\hline $\mathrm{FEV}_{1}$ & $3.22 \pm 0.83$ & $3.26 \pm 0.80$ & $3.29 \pm 0.82$ & $0.04(-0.05,0.13)$ & $0.06(-0.02,0.14)$ \\
\hline $\mathrm{FEV}_{1} / \mathrm{FVC}$ & $75.3 \pm 7.64$ & $76.7 \pm 7.3$ & $75.8 \pm 7.2$ & $0.22(-1.12,1.56)$ & $1.37(0.21,2.53)^{*}$ \\
\hline $\mathrm{FEF}_{25-75}$ & $2.75 \pm 1.16$ & $2.94 \pm 1.10$ & $2.87 \pm 1.20$ & $0.07(-0.12,0.26)$ & $0.20(0.04,0.36)^{*}$ \\
\hline TLco & $23.2 \pm 5.48$ & $23.3 \pm 5.5$ & $24.3 \pm 5.75$ & $0.95(0.32,1.59)^{*}$ & $0.26(-0.29,0.81)$ \\
\hline
\end{tabular}

$* P<0.05$

${ }^{a}$ Adjusted for age, sex, height, smoking status and pack years

\section{Discussion}

Genes involved in the inflammatory process are important potential modifiers of individual susceptibility to reduced lung function and respiratory symptoms. IL8 and TNF- $\alpha$ are important cytokines involved in inflammation of the airways. IL8 is a potent neutrophil chemoattractant and its cellular activity is mediated by the receptor CXCR2. TNF- $\alpha$ is released from macrophages and can switch on transcription of IL8. The complex interaction between these three proteins makes them interesting potential candidate genes for modulating risk of inflammatory disease. This is one of the first studies to examine polymorphisms in the IL8 and $C X C R 2$ genes and risk of reduced lung function and respiratory symptoms. The $T N F-\alpha$ gene has previously been investigated in relation to COPD. However, only one previous study has looked at this gene in an unselected community-based sample to determine if these genes have a role in some of the intermediate phenotypes associated with airway inflammation, such as reduced lung function.

There is considerable evidence to suggest that IL8 is an important cytokine released in response to environmental insults. For example, levels of IL8 are elevated in the BAL of smokers (Kuschner et al. 1996), and IL8 release is increased from the macrophages of cigarette smokers and COPD patients (Lim et al. 2000). Several SNPs have been described in IL8 (Renzoni et al. 2000; Rovin et al. 2002). The IL8 -251A allele has been associated with increased production of IL8 (Hull et al. 2000). To our knowledge only one study has investigated IL8 and risk of COPD, which did not find an association with the IL8 -251 polymorphism (Arinir et al. 2005).

Table 6 Respiratory symptoms by $T N F-\alpha$ genotype

\begin{tabular}{|c|c|c|c|}
\hline$T N F-\alpha-308$ & Cases $n(\%)$ & Controls $n(\%)$ & OR $(95 \% \mathrm{CI})^{\mathrm{a}}$ \\
\hline Wheeze & $n=189$ & $n=639$ & \\
\hline $\mathrm{A} / \mathrm{A}(n=24)$ & $7(3.7)$ & $17(2.7)$ & $1.27(0.51,3.18)$ \\
\hline $\mathrm{G} / \mathrm{G}(n=558)$ & $132(69.8)$ & $426(66.7)$ & 1.0 \\
\hline Dyspnoea (grade 3) & $n=15$ & $n=813$ & \\
\hline $\mathrm{A} / \mathrm{A}(n=24)$ & $2(13.3)$ & $22(2.7)$ & $4.25(0.74,24.4)$ \\
\hline Chronic cough & $n=70$ & $n=758$ & \\
\hline $\mathrm{A} / \mathrm{A}(n=24)$ & $2(2.9)$ & $22(2.9)$ & $0.85(0.19,3.79)$ \\
\hline $\mathrm{A} / \mathrm{G}(n=246)$ & $20(28.6)$ & $226(29.8)$ & $0.90(0.52,1.57)$ \\
\hline $\mathrm{G} / \mathrm{G}(n=558)$ & 48 (68.6) & $510(67.3)$ & 1.0 \\
\hline Chronic phlegm & $n=23$ & $n=805$ & \\
\hline
\end{tabular}

$* P<0.05$

${ }^{\mathrm{a}}$ Logistic regression adjusted for age, sex, current smoking and pack years 
Similarly, we did not find any association between the IL8 -251 polymorphism and respiratory symptoms or lung function.

Homozygotes for the $C X C R 2+785 \mathrm{~T}$ allele were found to have significantly higher TLco \%predicted, and heterozygotes for the CXCR2 $+785 \mathrm{~T}$ allele had significantly better $\mathrm{FEF}_{25-75} \%$ predicted. COPD is characterised both by decreased expiratory flow rates and abnormal gas exchange and these results suggest that the $C X C R 2+785 \mathrm{~T}$ allele may be associated with protection against these abnormalities. The only published genome-wide scan for loci linked to COPD-related phenotypes found evidence of linkage of the $C X C R 2$ region (chromosome $2 \mathrm{q}$, LOD score 4.12 at $222 \mathrm{cM})$ to a number of quantitative spirometric abnormalities (DeMeo et al. 2004; Silverman et al. 2002). No association of $\mathrm{FEV}_{1} / \mathrm{FVC}$ with the $C X C R 2$ gene was found in the present analysis, but the associations with $\mathrm{FEF}_{25-75}$ \%predicted and TLco \%predicted further support a role for this gene in the inflammatory component of airflow limitation.

The $C X C R 2+785$ polymorphism does not result in an amino acid substitution, so it is most likely that this polymorphism is nearby an as yet undiscovered polymorphism that has functional consequences for gene transcription, protein expression or stability. A previous study of this polymorphism found an association between systemic sclerosis and individuals homozygous for the $C X C R 2+785 \mathrm{C}$ allele (Renzoni et al. 2000). Two polymorphisms in the CXCR1 gene were found to be over represented in a study of COPD subjects (Stemmler et al. 2005). Overall, our results provide evidence to suggest that CXCR2 is an important and interesting new candidate gene potentially involved in regulating the inflammatory process in the airways.

Individuals with at least one $T N F-\alpha-308 \mathrm{~A}$ allele were found to have a significantly reduced $\mathrm{FEF}_{25-75}$ $\%$ predicted. Furthermore, the $T N F-\alpha-308$ AA genotype was found to be associated with an increased risk of dyspnoea. These symptoms are generally associated with small airways disease, which is caused by cigarette smoking and has been shown to progress to COPD (Hogg 2004). Despite this relationship we did not find any evidence of an interaction between the $T N F-\alpha-308$ genotype and smoking status.

The TNF- $\alpha-308$ polymorphism has been investigated in several previous studies of COPD. No association between the $T N F-\alpha-308 \mathrm{~A}$ allele and COPD has been shown in any of the previous studies of Caucasian COPD subjects (Higham et al. 2000; Keatings et al. 2000; Patuzzo et al. 2000; Sandford et al. 2001). However, the results are less consistent for studies of Asian populations. Two studies, one in a Taiwanese population (Huang et al. 1997) and one in a Japanese population (Sakao et al. 2001), reported a significantly higher prevalence of the $T N F-\alpha-308 \mathrm{~A}$ allele in the cases compared to controls. However, this result was not replicated in a subsequent Japanese population (Ishii et al. 2000). All of these studies, with the exception of the lung health study (LHS) (Sandford et al. 2001), were likely to be affected by a lack of statistical power due to the low frequency of the $T N F-\alpha-308$ AA genotype. This is also a likely explanation for our finding of an association with $T N F-\alpha-308$ AG heterozygotes, but not $T N F-\alpha-308$ AA homozygotes with $\mathrm{FEF}_{25-75}$.

The inflammatory process is extremely complex, with interactions between many cytokines including TNF- $\alpha$ and IL8. TNF- $\alpha$ stimulates the release of NF- $\kappa \mathrm{B}$, which in turn switches on transcription of IL8, which attracts neutrophils into the airways (Rahman et al. 2002). These protein interactions prompted an investigation of interaction between polymorphisms by fitting a gene $\times$ gene interaction term in the model. However, no evidence of an interaction between any of the polymorphisms was found for any of the traits examined.

In view of the lack of HWE shown by IL8, the association reported here should be interpreted with some reservations, but should not preclude IL 8 from further investigation in relation to COPD. Lack of HWE could be due to genotyping error or population stratification. To eliminate genotyping error as a possible explanation for the lack of HWE, we genotyped $10 \%$ of the sample using an alternative method, and did not find any discrepant results. We observed an excess of homozygotes, which can be caused by population dynamics such as inbreeding, or population stratification known as Wahlund's principle (Schaid and Jacobsen 1999). However, the likelihood of inbreeding in this randomly selected population from Melbourne is small. Population stratification due to sampling of different ethnic groups is another possible explanation for the deviation from HWE. All subjects in this analysis were of Caucasian descent; however, the multi-cultural structure of the Melbourne community means that population stratification cannot be entirely ruled out.

We found the overall prevalence of asthma symptoms such as wheeze and nocturnal dyspnoea to be quite high in our study group. However, the prevalence of asthma in Australia is among the highest in the world (Masoli et al. 2004). To examine this we compared the prevalence of self-reported respiratory symptoms between participants in the laboratory phase of the study and participants in only the initial screening questionnaire phase. We observed a significantly higher prevalence of wheeze in those that attended the laboratory but other respiratory symptoms and self-reported COPD were not associated with attendance. We did find significantly more current smokers among the non-participants and slightly more males (data not shown). However, this bias towards symptomatic non-smokers is unlikely to have affected the associations between genes and lung function. Due to the number of analyses conducted with many different outcomes, it might be argued that adjustment for multiple comparisons is necessary. However, for each gene there was an a priori hypothesis of an individual association with reduced lung function and respiratory symptoms. This was based on the role of these genes and their products in the inflammatory 
process. The $P$ values for the analyses are presented without adjustment and the results should be viewed as hypothesis-generating rather than proof that these polymorphisms are associated with lung function.

In conclusion, the association of three cytokine gene polymorphisms with lung function and respiratory symptoms has been analysed in a community-based study of older adults. Evidence of an association between the $T N F-\alpha-308 \mathrm{~A}$ allele and small airways disease was found, as indicated by a reduced $\mathrm{FEF}_{25-75}$ accompanied by respiratory symptoms. Furthermore, we have also found evidence that $C X C R 2$ may be associated with better lung function, suggesting the gene may be important in down-regulating the airway inflammatory response. This analysis suggests these genes are possibly important in modulating the inflammatory processes in the airways response to environmental insults and the lung ageing process.

Acknowledgements We acknowledge the financial support provided by The National Health \& Medical Research Council of Australia, Monash University, LEW Carty Research Fund, Windermere Foundation, Victorian Tuberculosis \& Lung Association and the Rebecca L Cooper Medical Research Foundation, to enable this study to be undertaken. We wish to thank Associate Professor David Johns for advice with regard to the lung function testing. We also acknowledge the assistance of Cathryn Wharton, Judi Wicking and Billy Skoric with data collection and Nicholas Harrap and Nadia Harun for assistance with DNA extraction.

\section{References}

American Thoracic Society (1994) Standardization of spirometry-1994 update. Am J Respir Crit Care Med 152:1107-1136

American Thoracic Society (1995) Single-breath carbon monoxide diffusing capacity (transfer factor). Recommendations for a standard technique-1995 update. Am J Respir Crit Care Med 152:2185-2198

Arinir U, Klein W, Rohde G, Stemmler S, Epplen JT, SchultzeWerninghaus G (2005) Polymorphisms in the interleukin- 8 gene in patients with chronic obstructive pulmonary disease. Electrophoresis 26:2888-2891

Barnes PJ (2000) Mechanisms in COPD: differences from asthma. Chest 117:10S-14S

Cacalano G, Lee J, Kikly K, Ryan AM, Pitts-Meek S, Hultgren B, Wood WI, Moore MW (1994) Neutrophil and B cell expansion in mice that lack the murine IL-8 receptor homolog. Science 265:682-684

DeMeo DL, Celedon JC, Lange C, Reilly JJ, Chapman HA, Sylvia JS, Speizer FE, Weiss ST, Silverman EK (2004) Genomewide linkage of forced mid-expiratory flow in chronic obstructive pulmonary disease. Am J Respir Crit Care Med 170:1294-1301

Ferrarotti I, Zorzetto M, Beccaria M, Gilè LS, Porta R, Ambrosino N, Pignatti PF, Cerveri I, Pozzi E, Luisetti M (2003) Tumour necrosis factor family genes in a phenotype of COPD associated with emphysema. Eur Respir J 21:444-449

Gore CJ, Crockett AJ, Pederson DG, Booth ML, Bauman A, Owen N (1995) Spirometric standards for healthy adult lifetime nonsmokers in Australia. Eur Respir J 8:773-782

Hajeer AH, Hutchinson IV (2000) TNF-alpha gene polymorphism: clinical and biological implications. Microse Res Tech 50:216228

Higham MA, Pride NB, Alikhan A, Morrell NW (2000) Tumour necrosis factor-alpha gene promoter polymorphism in chronic obstructive pulmonary disease. Eur Respir J 15:281-284
Hogg JC (2004) Pathophysiology of airflow limitation in chronic obstructive pulmonary disease. Lancet 364:709-721

Huang SL, Su CH, Chang SC (1997) Tumor necrosis factor-alpha gene polymorphism in chronic bronchitis. Am J Respir Crit Care Med 156:1436-1439

Hull J, Thomson A, Kwiatkowski D (2000) Association of respiratory syncytial virus bronchiolitis with the interleukin 8 gene region in UK families. Thorax 55:1023-1027

Ishii T, Matsuse T, Teramoto S, Matsui $\mathrm{H}$, Miyao M, Hosoi T, Takahashi H, Fukuchi Y, Ouchi Y (2000) Neither IL-1beta, IL1 receptor antagonist, nor TNF-alpha polymorphisms are associated with susceptibility to COPD. Respir Med 94:847-851

Keatings VM, Cave SJ, Henry MJ, Morgan K, O'Connor CM, FitzGerald MX, Kalsheker N (2000) A polymorphism in the tumor necrosis factor-alpha gene promoter region may predispose to a poor prognosis in COPD. Chest 118:971-975

Kuschner WG, D’Alessandro A, Wong H, Blanc PD (1996) Dosedependent cigarette smoking-related inflammatory response in healthy adults. Eur Respir J 9:1989-1994

Lim S, Roche N, Oliver BG, Mattos W, Barnes PJ, Fan Chung K (2000) Balance of matrix metalloprotease-9 and tissue inhibitor of metalloprotease-1 from alveolar macrophages in cigarette smokers. Regulation by interleukin-10. Am J Respir Crit Care Med 162:1355-1360

Masoli M, Fabian D, Holt S, Beasley R, Global Initiative for Asthma (GINA) Program (2004) The global burden of asthma: executive summary of the GINA Dissemination Committee report. Allergy 59:469-478

Matheson MC, Benke G, Raven J, Sim MR, Kromhout H, Vermeulen R, Johns DP, Walters EH, Abramson MJ (2005) Biological dust exposure in the workplace is a risk factor for chronic obstructive pulmonary disease. Thorax 60:645-651

Norzila MZ, Fakes K, Henry RL, Simpson J, Gibson PG (2000) Interleukin-8 secretion and neutrophil recruitment accompanies induced sputum eosinophil activation in children with acute asthma. Am J Respir Crit Care Med 161:769-774

Patuzzo C, Gile LS, Zorzetto M, Trabetti E, Malerba G, Pignatti PF, Luisetti M (2000) Tumor necrosis factor gene complex in COPD and disseminated bronchiectasis. Chest 117:1353-1358

Pesci A, Balbi B, Majori M, Cacciani G, Bertacco S, Alciato P, Donner C (1998) Inflammatory cells and mediators in bronchial lavage of patients with chronic obstructive pulmonary disease. Eur Respir J 12:380-386

Qiu Y, Zhu J, Bandi V, Atmar RL, Hattotuwa K, Guntupalli KK, Jeffery PK (2003) Biopsy neutrophilia, neutrophil chemokine and receptor gene expression in severe exacerbations of chronic obstructive pulmonary disease. Am J Respir Crit Care Med 168:968-975

Quanjer PH, Dalhuijsen A, van Zomeren BC (1983) Summary equations of reference values. Bull Eur Physiopathol Respir 19[Suppl 5]:45-51

Rahman I, Gilmour P, Jimenez LA, MacNee W (2002) Oxidative stress and TNF-alpha induce histone acetylation and NF-kappaB/AP-1 activation in alveolar epithelial cells: potential mechanism in gene transcription in lung inflammation. Mol Cell Biochem 234/235:239-248

Renzoni E, Lympany P, Sestini P, Pantelidis P, Wells A, Black C, Welsh K, Bunn C, Knight C, Foley P, du Bois RM (2000) Distribution of novel polymorphisms of the interleulin- 8 and CXC receptor 1 and 2 genes in systemic sclerosis and cryptogenic fibrosing alveolitis. Arthritis Rheum 43:1633-1640

Rovin BH, Lu L, Zhang X (2002) A novel interleukin-8 polymorphism is associated with severe systemic lupus erythematosus nephritis. Kidney Int 62:261-265

Rutgers SR, Timens W, Kaufmann HF, van der Mark TW, Koeter GH, Postma DS (2000) Comparison of induced sputum with bronchial wash, bronchoalveolar lavage and bronchial biopsies in COPD. Eur Respir J 15:109-115

Sakao S, Tatsumi K, Igari H, Shino Y, Shirasawa H, Kuriyama T (2001) Association of tumor necrosis factor alpha gene promoter polymorphism with the presence of chronic obstructive pulmonary disease. Am J Respir Crit Care Med 163:420-422 
Sandford AJ, Chagani T, Weir TD, Connett JE, Anthonisen NR, Pare PD (2001) Susceptibility genes for rapid decline of lung function in the lung health study. Am J Respir Crit Care Med 163:469-473

Schaid DJ, Jacobsen SJ (1999) Biased tests of association: comparisons of allele frequencies when departing from hardyweinberg proportions. Am J Epidemiol 149:706-711

Silverman EK, Palmer LJ, Mosley JD, Barth M, Senter JM, Brown A, Drazen JM, Kwiatkowski DJ, Chapman HA, Campbell EJ, Province MA, Rao DC, Reilly JJ, Ginns LC, Speizer FE, Weiss ST (2002) Genomewide linkage analysis of quantitative spirometric phenotypes in severe early-onset chronic obstructive pulmonary disease. Am J Hum Genet 70:1229-1239

Stemmler S, Arinir U, Klein W, Rohde G, Hoffjan S, Wirkus N, Reinitz-Rademacher K, Bufe A, Schultze-Werninghaus G,
Epplen JT (2005) Association of interleukin-8 receptor alpha polymorphisms with chronic obstructive pulmonary disease and asthma. Genes Immun 6:225-230

Strieter RM (2002) Interleukin-8: a very important chemokine of the human airway epithelium. Am J Physiol Lung Cell Mol Physiol 283:L688-L689

Sun G, Stacey MA, Vittori E, Marini M, Bellini A, Kleimberg J, Mattoli S (1998) Cellular and molecular characteristics of inflammation in chronic bronchitis. Eur J Clin Invest 28:364372

Thomas PS (2001) Tumour necrosis factor-alpha: the role of this multifunctional cytokine in asthma. Immunol Cell Biol 79:132140

Ye S, Dhillon S, Ke X, Collins AR, Day IN (2001) An efficient procedure for genotyping single nucleotide polymorphisms. Nucleic Acids Res 29:E88-E88 